\title{
Role of Conidial Fusion in Infection by Botrytis cinerea on Cucumber Leaves*
}

\author{
Katsumi AKUtsu**, Keido Kō** and Tomomasa Misato** \\ 阿久津克己**・黄 耿堂** 見里朝正**：兏色かび病菌の感染に \\ おける分生胞子融合の役割についで
}

\begin{abstract}
Glucose or sucrose enhanced germination of conidia, formation of primary appressoria and elongation of superficial hyphae, but did not induce infection by Botrytis cinerea on cucumber leaves. By enhancing conidial concentration in glucose or sucrose solution, however, $B$. cinerea produced significant lesions. When the conidial concentration exceeded $1 \times$ $10^{7}$ conidia $/ \mathrm{ml}$ in $5 \%$ glucose or $5 \%$ sucrose solution, inoculated conidia fused with each other and formed netted structures on cucumber leaves. Similar fusions were also reported in the process of infection by Fusarium nivale. Hyphae growing out from the netted structures were more vigorous than hyphae or germ tube from single conidia. The hyphae from the structures formed appressoria, which belong to the second type of simple appressoria group. From the appressoria, infection pegs developed through epidermal cell walls. In 24 hr after inoculation, infection hyphae were observed in the epidermal cells, and also in mesophyll cells $48 \mathrm{hr}$ after inoculation. It seems that glucose induces the conidial fusion and formation of the netted structures under the condition of more than a given concentration of conidia. The netted structures are thought to play a role of supplying nutrients for the infection by $B$. cinerea.
\end{abstract}

(Received August 29, 1980)

\section{Introduction}

Botrytis cinerea Pers. ex Pers. is a ubiquitous fungus which caused the characteristic gray mould diseases of many plants throughout the world, especially under cool, humid conditions. Previous reports indicated that amending $B$. cinerea conidia with exogenous nutrients stimulated pathogenic aggressiveness on crop plants ${ }^{1 \sim 4,6,12,14 \sim 16)}$. Clark and Lorbeer reported that none of 18 isolates of $B$. cinerea produced significant lesions on onion leaves inoculated with conidia in water, and that in conidial inoculation, the fungus required exogenous nutrients for pathogenesis ${ }^{8}$.

Clark et al. reported that glucose enhanced germination of conidia, formation of appressoria and elongation of superficial hyphae, but did not induce formation of lesions on onion leaves $^{7)}$. Similary, we found that $B$. cinerea could not infect cucumber leaves in the presence of glucose by the inoculation with lower concentration of conidia. By enhancing the conidial concentration, however, $B$. cinerea produced visible signs of infection rapidly

\footnotetext{
* The part of this paper was presented at the Annual Meeting of the Phytopathological Society of Japan, Tokyo, April 3, 1980

** The Institute of Physical and Chemical Research, Wako, Saitama 351, Japan 理化学研究所
} 
in the presence of glucose.

This study was undertaken to investigate the mechanism of infection by $B$. cinerea induced by enhancing the conidial concentration in the presence of glucose.

\section{Materials and Methods}

Test fungus. A culture of Botrytis cinerea was obtained from National Institute of Agricultural Sciences. The fungus preserved for a long period on potato-dextrose agar at $20 \mathrm{C}$ in the dark. The fungus produced abundant conidia when grown on yeast-glucose agar (YGA) and placed, 3 days after incubation, under BLB (Black light lamp) light for 2 days $^{11}$. Conidia were harvested from 7 day-old YGA cultures by adding $20 \mathrm{ml}$ of sterile distilled water, and gently scraping the surface with a sterile brush. The conidial suspension was filtered through two layers of sterile paper (Kleenex tissues) to remove mycelial fragments.

Test plant. The cucumber variety used in this study was "Sagami Hanjiro". The seeds were sown on sterile soil in pots, which were kept for 10 days under the condition of $28 \mathrm{C}$ and $60 \%$ relative humidity. Subsequently primary leaves were cut into disks of $15 \mathrm{~mm}$ diameter with cork borer and placed on moist filter papers in sterile Petri dishes (Terumo).

Inoculation. Conidial suspensions were adjusted to $1 \times 10^{5}, 1 \times 10^{6}, 1 \times 10^{7}$ and $1 \times$ $10^{8}$ conidia/ml in $5 \%$ glucose, $5 \%$ sucrose, $5 \%$ peptone or distilled water solution. Cucumber leaf disks were inoculated with $5 \mu \mathrm{l}$ droplet of each conidial suspension per leaf disk. After inoculation, the leaf disks were incubated at $20 \mathrm{C}$ under $12 \mathrm{hr}$-illumination of fluorescent light per day.

Light microscopical observation. The inoculated leaves were collected 6, 12 , 18, 24 and $48 \mathrm{hr}$ after inoculation, and fixed in FAA (Formalin : Ethanol: Acetic acid $=1: 1: 1$ ) solution. After fixation the samples were stained with cotton blue solution, and examined by light microscope.

\section{Results}

\section{Relation of disease and conidial concentration}

When conidial suspension was adjusted to $1 \times 10^{5}$ conidia $/ \mathrm{ml}$ in $5 \%$ glucose, $5 \%$ sucrose, $5 \%$ peptone or distilled water, $B$. cinerea did not produce expanding lesions on cucumber leaf disks (Table 1). The fungus produced typical lesions on the leaf disks, however, when the conidial concentration was enhanced to $1 \times 10^{7}$ conidia/ml in $5 \%$ glucose or $5 \%$ sucrose solution (Table 1). In inoculation with the same concentration in $5 \%$ peptone or water, lesion formation was not observed (Table 1 ). When the conidial concentration was enhanced to $1 \times 10^{8}$ conidia $/ \mathrm{ml}$
Table 1. Effects of conidial concentration and exogenous nutrients on infection by Botrytis cinerea on cucumber leaves

\begin{tabular}{lcccc}
\hline \hline \multirow{2}{*}{$\begin{array}{l}\text { Exogenous } \\
\text { nutrients }\end{array}$} & \multicolumn{4}{c}{$\begin{array}{c}\text { Conidial concentration } \\
\text { (numbers/ml) }\end{array}$} \\
\cline { 2 - 5 } & $1 \times 10^{5}$ & $1 \times 10^{6}$ & $1 \times 10^{7}$ & $1 \times 10^{8}$ \\
\hline Glucose & $0^{2}$ & 0 & 5 & 12 \\
Sucrose & 0 & 0 & 3 & 10 \\
Peptone & 0 & 0 & 0 & 0 \\
Control $^{\text {b) }}$ & 0 & 0 & 0 & 0 \\
\hline
\end{tabular}

a) Diameter of lesion (mm)

b) Distilled water 


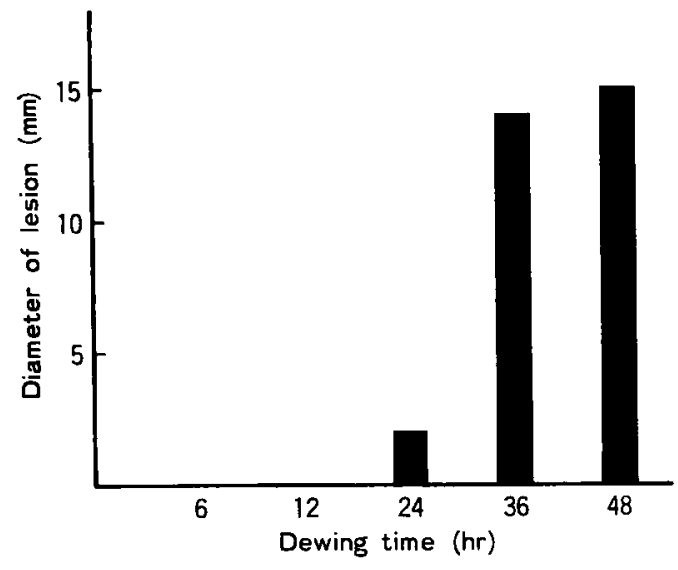

Fig. 1. Relation of dewing time of conidial suspension with $5 \%$ glucose and lesion formation by Botrytis cinerea on cucumber leaves.
Table 2. Germination of conidia of Botrytis cinerea treated with glucose or sucrose on cucumber leaves

\begin{tabular}{cc}
\hline Exogenous nutrients & Germination $(\%)^{\mathrm{a})}$ \\
\hline Glucose & 94.7 \\
Sucrose & 93.5 \\
Control $^{\mathrm{b})}$ & 58.7
\end{tabular}

a) Ratio of germinated conidia to total inoculated conidia

b) Distilled water

in $5 \%$ glucose or $5 \%$ sucrose, the largest lesions were formed, but in the same concentration, the lesion formation was

not observed when inoculated in $5 \%$ peptone or distilled water (Table 1 ).

\section{Relation of disease and dewing times of the suspension}

We examined the dewing time of the inoculum-droplet necessary for lesion formation. When the droplet was dewing for more than $24 \mathrm{hr}$, the lesion formation was observed (Fig. 1). It was known that the dewing time of more than $24 \mathrm{hr}$ were necessary for infection of the fungus on cucumber leaves.

\section{Light microscopical observation}

In order to investigate the mechanism of infection induced by enhancing the conidial concentration in the presence of glucose or sucrose, we examined each process of the infection by $B$. cinerea on cucumber leaf disks with light microscope.

Germination of conidia was considerably lower in water than in $5 \%$ glucose or $5 \%$ sucrose solution (Table 2). Germ tubes formed after $3 \mathrm{hr}$ of inoculation and ceased elongation in distilled water after $6 \mathrm{hr}$. In the suspensions adjusted to $1 \times 10^{5}$ conidia/ml in $5 \%$ glucose or $5 \%$ sucrose solution, germ tubes elongated rapidly, and primary appressoria were formed terminally $6 \mathrm{hr}$ after inoculation, but penetration into epidermal cells by the appressoria was not observed (Plate I-1). Subsequently, superficial hyphae elongated from the appressoria on the leaf surface, and infection was not observed within $48 \mathrm{hr}$ after inoculation.

In the suspension adjusted to $1 \times 10^{8}$ conidia/ml in $5 \%$ glucose or $5 \%$ sucrose solution, the inoculated conidia fused with each other, and formed netted structures (Plate I-2). The netted structures were not observed when inoculated with suspension adjusted to 1 $\times 10^{8} \mathrm{conidia} / \mathrm{ml}$ in distilled water.

The netted structures were formed with fusion of a few conidia, and various fusion types were found among them. The conidial fusion could be roughly classfied in to three types. The first type is a conidium-to-conidium fusion, in which each conidium connectes with a short connective hypha, and this type was dominant (Plate I-3). The second type 
is a germ tube-to-conidium fusion, in which the tip of the germ tube connectes with the conidium directly (Plate I-4). In this type, there is a septum in the germ tube fused with the conidium, and for this fact, the second type is distinguished from the first type. The third type is a germ tube-to-germ tube fusion, and there are two kinds in the way of fusion in this type. In one case each germ tube fuses directly(Plate I-5), and in the other each germ tube fuses by way of a connective hypha indirectly (Plate I-6). The connective hyphae showed typical S-form, and the length varied. Each type of the conidial fusion was diagramed in Plate II-1.

The netted structures were usually formed by fusion of three to four conidia (Plate I-2). In $18 \mathrm{hr}$ after inoculation, hyphae growing out from the netted structure were observed, and the hyphae were larger in size than hyphae or germ tubes from the single conidia (Plate II-2 and 3). In $24 \mathrm{hr}$ after inoculation, the hyphae from the structures, coming in contact with epidermal cell junctures, formed well-developed appressoria (Plate III-1), and the appressoria were usually delimited from the hyphae by septa (Plate III-2). According to Emmett's classfication of appressoria ${ }^{9}$, the appressoria belong to the second type of simple appressoria group. Also, at the same time, invasion into the epidermal cells by the appressoria was observed (Plate III-3). From the appressoria, infection pegs developed through the epidermal cell junctures, and papilla-like structures were observed around them (Plate I-6). In $48 \mathrm{hr}$ after inoculation, infection hyphae were observed not only in epidermis but also in mesophyll cells (Plate III-4).

\section{Discussion}

Conidial germination and infection by $B$. cinerea are reported to be stimulated significantly by exogenous nutrients, such as diffusate from onion-leaf lacuna, filtrate from cattail pollen, and Czapek-Dox broth ammened with yeast extract ${ }^{8)}$. Glucose has been known to stimulate infection by $B$. cinerea as an exogenous nutrient $t^{5,12)}$, but on the other hand, it is reported that $B$. cinerea could not infect in the presence of glucose ${ }^{8}$. Light microscopical observations revealed that glucose enhanced conidial germination, formation of primary appressoria and elongation of superficial hyphae, but did not induce formation of secondary appressoria and penetration into cucumber leaves. As mentioned above, there are many reports that showed the contrary results concerning effects of glucose on infection by $B$. cinerea.

In this study, we found a clue to solve this contradiction. By enhancing concentration of conidia, $B$. cinerea produced visible signs of the infection in the presence of glucose. It is thought that the contradictory results may be caused by difference of the conidial concentration used. Also, from the light microscopical observation, it was obvious that $B$. cinerea infected cucumber leaves by the way differed from infection cushion known till now ${ }^{14)}$. In the presence of glucose, conidia of $B$. cinerea fused each other and formed netted structures, and infection was induced by appressoria formed from the netted structures. Similarly, germ tubes from single conidia formed the second type of simple appressoria group, but its size was small. The appressoria from the single conidia failed to penetrate into cucumber leaves. Also, it is known that differing from $B$. cinerea, $B$. squanosa is capable of infection into onion leaves without exogenous nutrient amendment, and that the difference in the nutrient dependency of the two species may relate to the fact that the calculated volume of $B$. squanosa conidia $\left(1860 \mu \mathrm{m}^{3}\right)$ is appreciably greater 
than that for $B$. cinerea $\left(60 \mu \mathrm{m}^{3}\right)^{8)}$. These facts suggest that the netted structures by conidial fusion play a role of supplying nutrients for the infection by $B$. cinerea.

It has also reported that such netted structures were formed in.the process of infection by Fusarium nivale, and the structures were named as conidial complex ${ }^{13)}$. They ${ }^{13)}$ considered in the report that formation of the conidial complex was relating to supply of nutrients required for the infection by $F$. nivale. This suggests that $F$. nivale and $B$. cinerea are similar in dependency on nutrients for infection.

In $B$. cinerea, the infection was induced by the netted structures when inoculated in glucose or sucrose solution, but when inoculated in infection inducers (onion-leaf lacuna diffusate, cattail pollen filtrate $e t c$.), the infection was induced by infection cushions. It is thought that $B$. cinerea can induce infection by different infection ways in accordance with the kinds of exogenous nutrients.

Inducers of conidial fusion has been investigated in $F$. nivale by Ito $e t$ al., and it is obvious that the inducer exists in a certain fraction of rice-leaf extract ${ }^{10}$. In $B$. cinerea, it is necessary to investigate inducers of conidial fusion for solving the relation to conidial fusion and pathogenicity, and we shall study about the inducers of conidial fusion.

\section{Ackowledgements}

The authors are grateful to Mr. Y. Matsuzawa and Mrs. Y. Kobayashi of our institute for their skillful technical assistance in conducting this work.

\section{Literature cited}

1. Barash, I., Klieswicz, J. M. and Kosuge, T. (1963). Phytopathology 53 : 1137 (Abstr.).

2. Brown, W. (1922). Ann. Bot. 36:101-119.

3. Brown, W. and Harvey, C. C. (1927). Ann. Bot. $41: 643-662$.

4. Carlile, M. J. and Sellin, M. A. (1963). Trans. Br. Mycol. Soc. 46: 15-18.

5. Chou, L.G. (1972). Phytopathology $62: 1107$ (Abstr.).

6. Chou, L. G. and Preece, T. F. (1968). Ann. Appl. Biol. 62: 11-22.

7. Clark, C. A. and Lorbeer, J. W. (1976). Phytopathology 66: 1279-1289.

8. Clark, C. A. and Lorbeer, J. W. (1977). Ibid. $67: 212-218$.

9. Emmett, R.W. and Parbery, D. G. (1975) Ann. Rev. Phytopath. 13: 147-167.

10. Ito, M., Furukawa, J., Okuda, S. and Yamaguchi, T. (1979). In "Regulation Mechanism of Infection Processes in Plants", p. 1-8, Summer Seminar held by the Phytopathological Society of Japan, Nagano, June 14, 1979.

11. Ko, K., Matsuzawa, Y., Adachi, Y., Watanabe, T. and Misato, T. (1978). Reports I.P.C.R. 54 : 45-48.

12. Kosuge, T. and Hewitt, W. B. (1964). Phytopathology 54 : 167-172.

13. Naito, H., Akai, S. and Koshimizu, Y. (1975). Ann. Phytopath. Soc. Japan 41 : 477-491.

14. Sharman, S. and Heale, J. B. (1979). Trans. Br. Mycol. Soc. 73 : 147-154.

15. Shiraishi, M., Fukutomi, M. and Akai, S. (1970). Ann. Phytopath. Soc. Japan 36: 297-303.

16. Yoder, O.C. and Whalen, M. L. (1970). Can. J. Bot. 53: 691-699. 


\title{
和 文 摘 要
}

\section{灰色かび病菌の感染における分生胞子融合の役割について}

\author{
阿久津克己・黄 耿堂・見里朝正
}

\begin{abstract}
灰色かび病菌（Botrytis cinerea）の分生胞子を蒸留水，5\%グルコース，5\%フラクトース，5\%ペプト

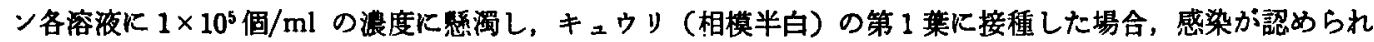
ない。ところが接種源の胞子濃度を高めると，5\%クルコース，5\%フラクトース照濁液接種で感染が認め

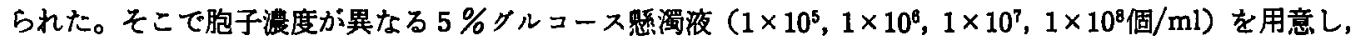
キュウリ第 1 葉に接種し，释時的に光顕観察した。低浱度 $\left(1 \times 10^{5}, 1 \times 10^{8}\right.$ 個 $\left./ \mathrm{ml}\right)$ 接種葉では，胞子は発芽 後, 発芽管先端に付着器 (simple appressoria 群の第 2 型) を形成し，侵入を試みるが，組織内人の侵入 は認められなかった。高淡度 $\left(1 \times 10^{7}, 1 \times 10^{8}\right.$ 個/ml）接種葉では，险接した胞子間で胞子同士，発芽管と 胞子，あるいは発芽管同士が融合し，網目状の構造体を形成した。この構造体は内藤らがイネ褐色葉枯病菌 （Fusarium nivale）で報告した分生胞子複合体と類似した形態を示す。この網目状の構造体から分岐した菌 系先端に付着器（simple appressoria 群の第 2 型）が形成され，角皮侵入しているのが锤察された。胞子 濃度の高い条件下で，グルコースは胞子間融合，網目状棈造体の形成を誘導することが考えられる。また網 目状棈造体は感染に要するエネルギーの補給に役立つるのと考えられる。
\end{abstract}

\section{Plate I.}

\section{Explanation of Plates}

1. Primary appressoria failed in penetration into epidermal cells of cucumber leaf. $\times 600$.

2. Netted structures formed on the surface of cucumber leaf. $\times 300$.

3. Conidium-to-conidium fusion on cucumber leaf. $\times 600$.

4. Germ tube-to-conidium fusion on cucumber leaf. $\times 600$

5. Germ tube-to-germ tube fusion on cucumber leaf. $\times 600$.

6. Germ tube-to-germ tube fusion by connective hypha on cucumber leaf. $\times 600$.

Plate II.

1. Diagram of various types of conidial fusion by Botyrtis cinerea on cucumber leaves. (1) First type fusion, (2) Second type fusion, (3) Third type fusion; A. Direct fusion by germ tube, B. Indirect fusion by connective hypha.

2. Hyphae growing out from netted structures on cucumber leaf. $\times 600$.

3. Germ tube and hypha growing out from a single conidium on cucumber leaf. $\times 600$.

Plate III.

1. Appressoria formed in the hyphae from the netted structures. $\times 300$.

2. An appressorium formed in the hypha from the netted structures. $\times 600$.

3. Penetration into the epidermal cells by the appressoria formed in the hyphae from the netted structures. $\times 300$.

4. Infection hyphae in the epidermal cells and mesophyll cells of cucumber leaf. $\times 150$.

\footnotetext{
Abbreviation

a, appressorium; c, conidium; ch, connective hypha; e, epidermal cell ; $f$, point of fusion; gt, germ tube; $i$, point of infection; ih, infection hypha; $m$, mesophyll cell; $p$, papilla-like structure; pa, primary appressorium; s, septum; sh, superficial hypha.
} 


\section{Plate I}
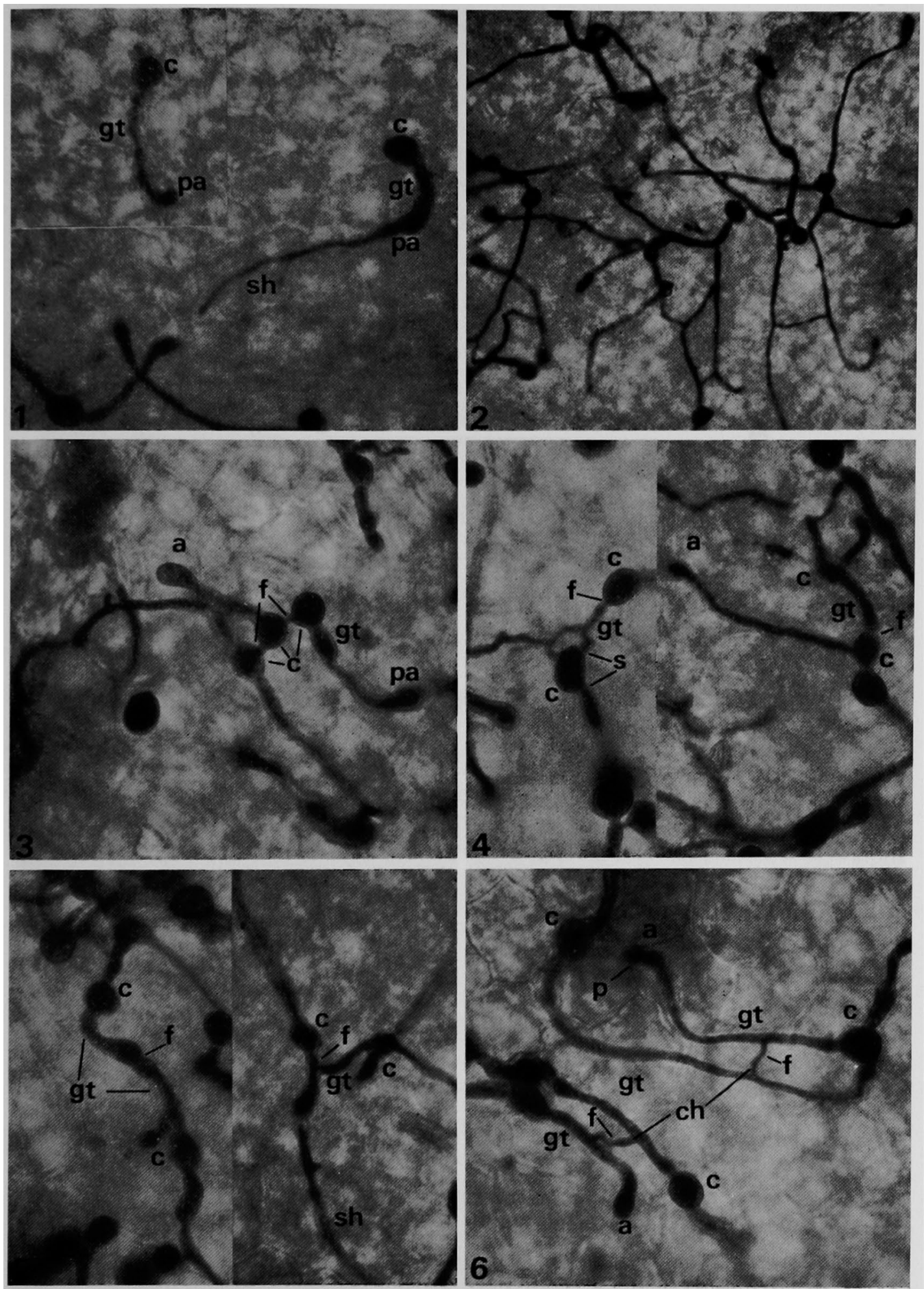
Plate II

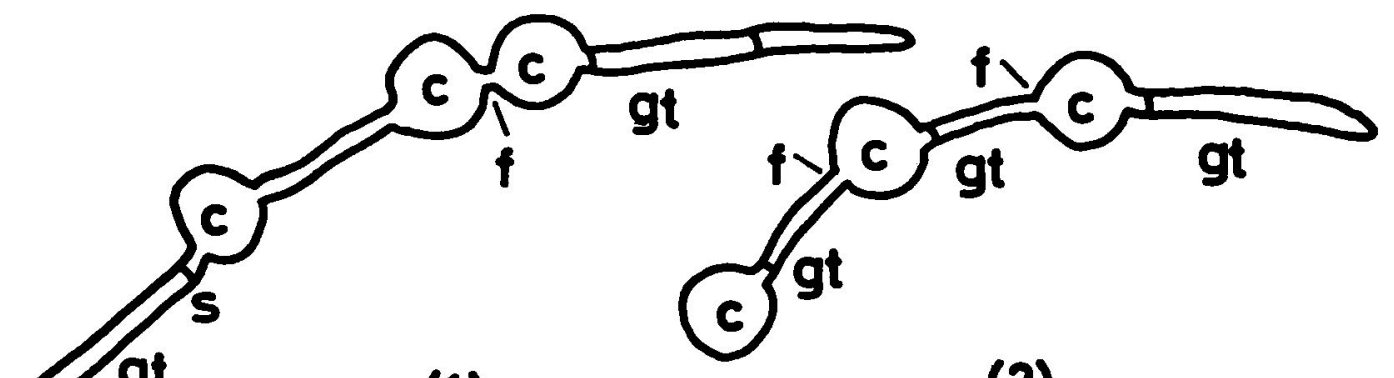

(1)

(2)

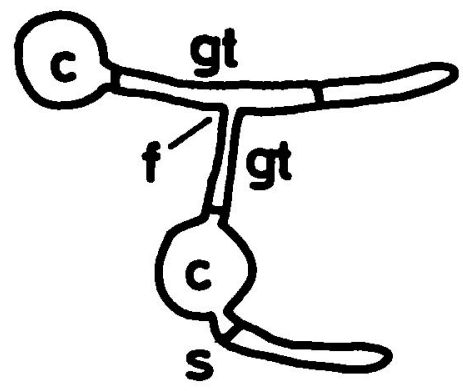

A

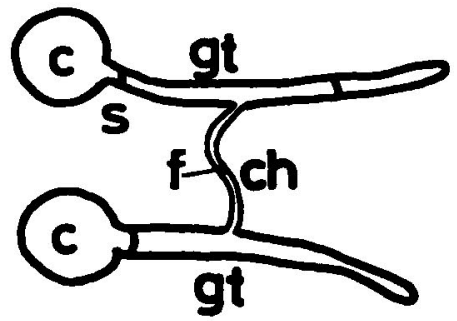

B

(3)

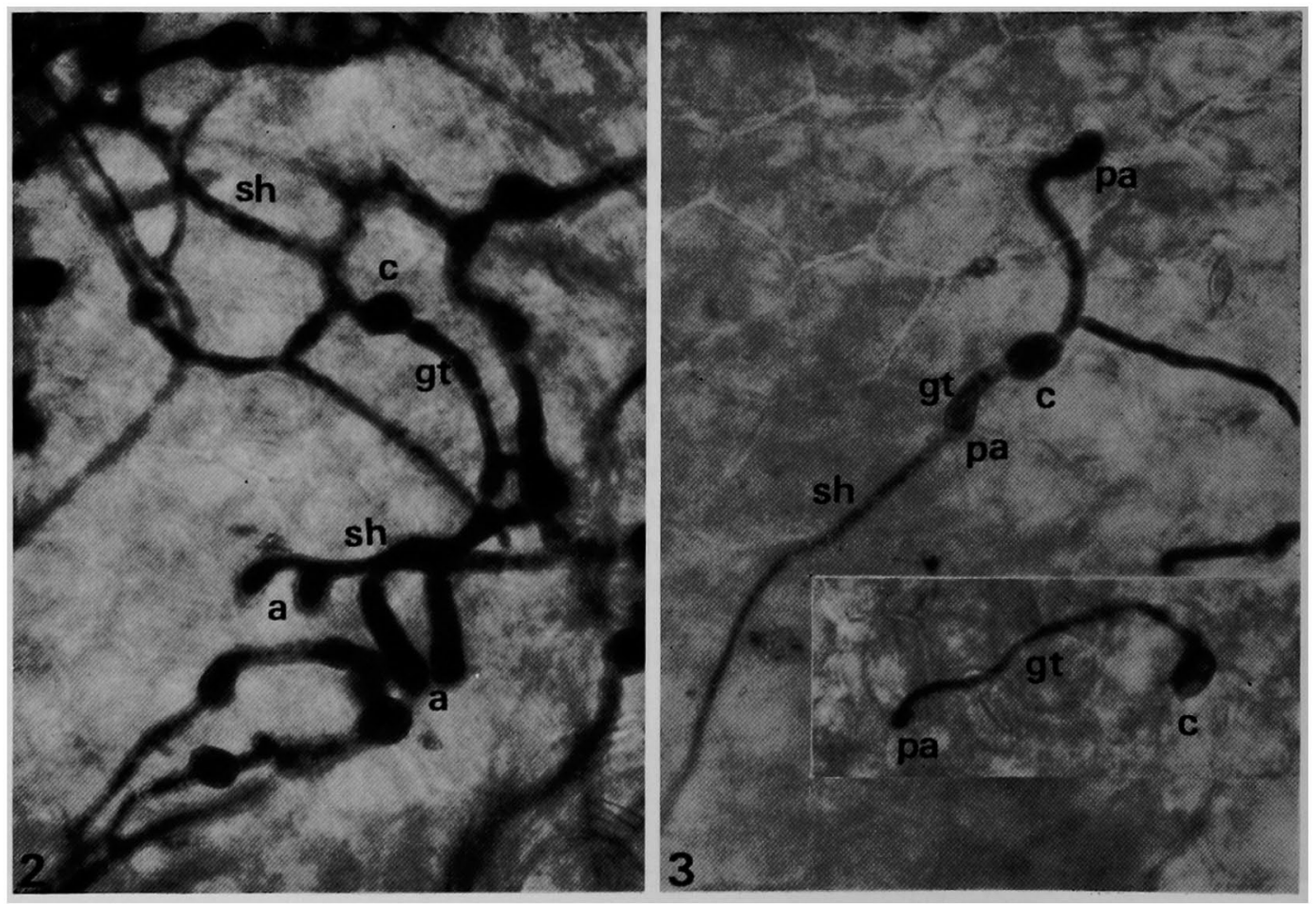




\section{Plate III}
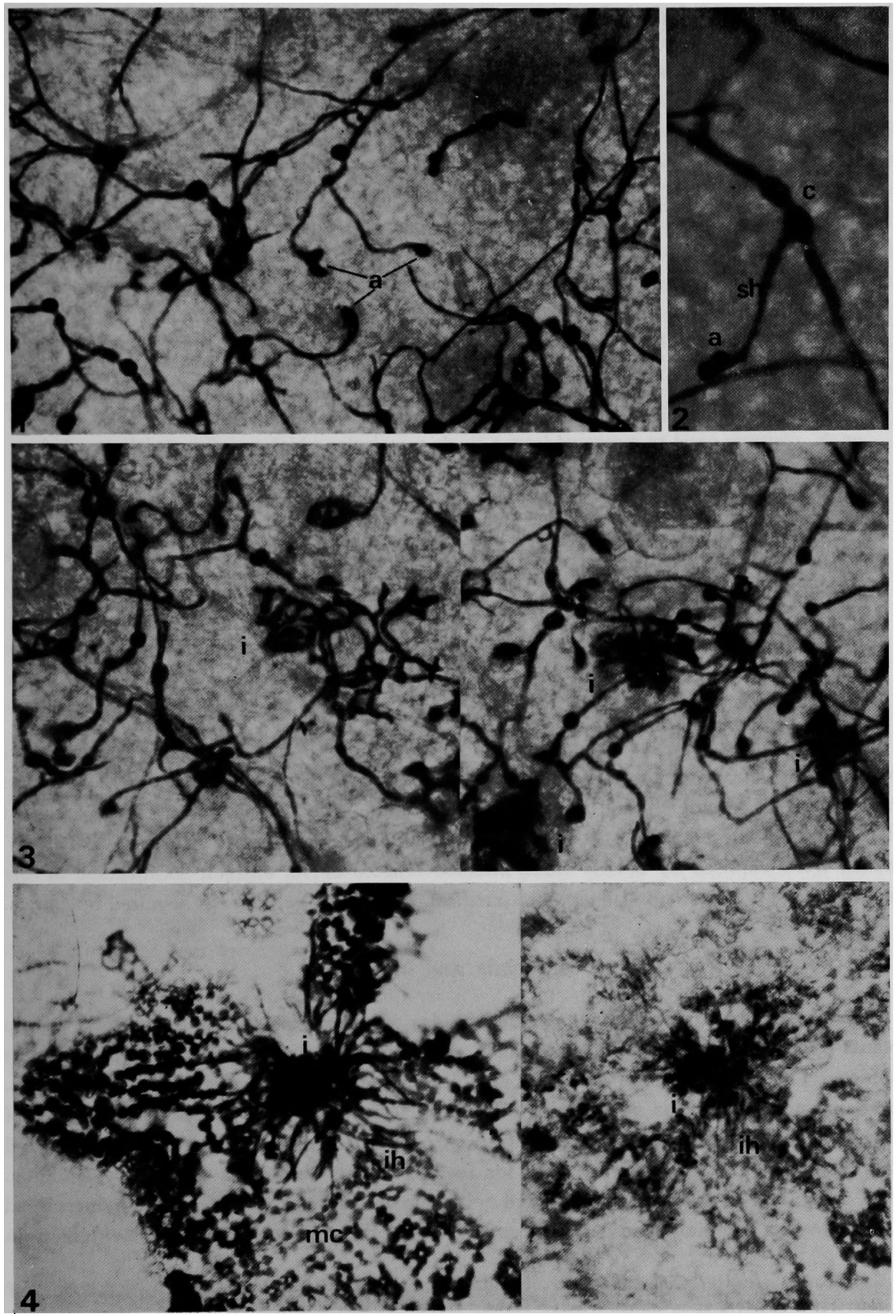